\title{
THE CONSTRUCTION OF ENVIRONMENTAL INDICATORS FOR DETERMINATION OF PERFORMANCE OF ESG INDICATORS TO SUPPORT DECISION-MAKING OF INVESTORS
}

\author{
Alena Kocmanová ${ }^{1}, Z_{\text {deněk Karpíšek }}^{2}$, Markéta Klímková ${ }^{3}$ \\ Faculty of Business and Management, Brno University of Technology, Kolejni 4, 61200 Brno, Czech Republic \\ E-mails: ${ }^{1}$ kocmanova@fbm.vutbr.cz (corresponding author); ${ }^{2}$ karpisek@fme.vutbr.cz; ${ }^{3}$ klimkova@fbm.vutbr.cz
}

Received 29 June 2012; accepted 19 September 2012

\begin{abstract}
This contribution deals with the construction of environmental indicators, serving investors for the assessment of complex performance of companies in accordance with social and corporate governance indicators, the so-called ESG performance indicators. The research project "Construction of Methods for Multifactor Assessment of Company Complex Performance in Selected Sectors", solved by the team of authors has been introduced. In recent years, investment managers have preferred the importance of ESG indicators showing long-term sustainable performance of those companies in which they have invested their financial resources. The objective of presented contribution is the proposal of environmental indicators, i.e. key ESG performance indicators. Environmental indicators are used not only for decision-making, but also for determination of sustainable value. A number of successive steps have been taken to construct environmental indicators and a combination of various statistical methods has been employed. An empirical analysis of environmental performance indicators for the companies operating in the processing industry according to CZ-NACE has been carried out on the basis of the analysis of sources, suggested by international organisations and voluntary environmental instruments. Environmental performance indicators, facilitating investors to decide on their investment activities and forming the part of key ESG-performance indicators, represent expected results of the empirical research.
\end{abstract}

Keywords: environmental indicators, performance, manufacturing industry according to Classification of Economic Activities Czech Republic, empirical research, T-test, regression function, key performance indicators, decision-making, measurement.

JEL Classification: Q50, Q56.

\section{APLINKOSAUGOS RODIKLIŲ NUSTATYMAS VEIKLAI VERTINTI PAGAL ASV VEIKLOS KRITERIJUS IR INVESTUOTOJŲ SPRENDIMAMS PAREMTI}

\author{
Alena Kocmanová ${ }^{1}$, Zdeněk Karpíšek $^{2}$, Markéta Klímková ${ }^{3}$ \\ Brno technologijos universitetas, Kolejní 4, 61200 Brno, Čekijos Respublika \\ El.paštas: ${ }^{1}$ kocmanova@fbm.vutbr.cz; ${ }^{2}$ karpisek@fme.vutbr.cz; ${ }^{3}$ klimkova@fbm.vutbr.cz
}

Iteikta 2012-06-29; priimta 2012-09-19

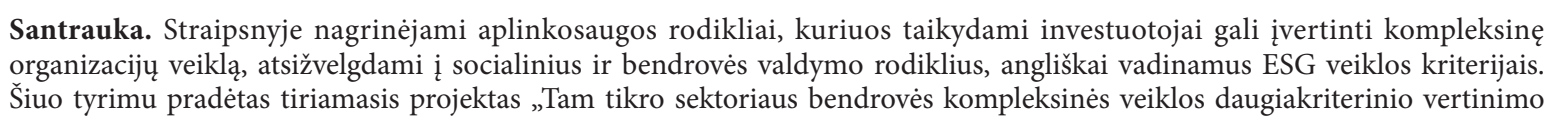


metodų kūrimas“. Pastaraisiais metais investicijų valdytojai teikia pirmenybę ESG veiklos rodikliams, kuriuos taikant galima įvertinti darnią bendrovių, ị kurias investuota, veiklą. Tyrimo tikslas - pasiūlyti aplinkosaugos rodiklius, t. y. vienus pagrindinių ESG veiklos kriterijų. Šie rodikliai naudojami ne tik priimant sprendimus, bet ir nustatant darnią vertę. Nuosekliai parinkti aplinkosaugos rodikliai ir pritaikytas ịvairių statistinių metodų rinkinys rodiklių reikšmèms nustatyti. Atliktas įmonių, veikiančių apdirbamojoje pramoneje pagal CZ-NACE, aplinkosaugos veiklos rodiklių empirinis tyrimas. Aplinkosaugos veiklos rodikliai, leidžiantys investuotojams spręsti apie investicinę veiklą ir sudarantys ESG veiklos rodiklių dalį, išreiškia tikètinus empirinio tyrimo rezultatus.

Reikšminiai žodžiai: aplinkosaugos rodikliai, veikla, apdirbamoji pramonė pagal CZ-NACE, aplinkosaugos aspektai, empirinis tyrimas, regresijos funkcija, pagrindiniai veiklos rodikliai, sprendimų prièmimas, matavimas.

\section{Introduction}

In recent years, investment managers have preferred the importance of ESG indicators showing long-term performance of those companies in which they have invested their financial resources. Surveys indicate that investors are more and more convinced that ESG integration into their investment decisions maximizes their long-term interest and that good corporate governance and sustainability contribute to creation of long-term value for shareholders.

The project holder - Faculty of Business and Management, Brno University of Technology (FBM BUT) - is involved in ESG indicators in the processing sector in the Czech Republic within the framework of the Project No. P403/11/2085 "Construction of Methods for Multifactor Assessment of Company Complex Performance in Selected Sectors" funded by the Grant Agency of the Czech Republic (GACR).

The objective of presented contribution is to propose a method of selection of environmental performance indicators at the corporate level, supporting decision-making of investors and being the part of ESG indicators and Integrated Reporting. Application of proposed methodology is clearly illustrated with an example of environmental indicators for performance. Reaching the objective is divided into successive steps. Individual stages of selection of indicators, including description of applied methods, have been defined in the methodology.

Development of research in the area of corporate performance evaluation and corporate sustainability reporting in the Czech Republic has been described by authors (Hřebíček, Soukupová 2009; Kocmanová, Dočekalová 2011; Ritschelova et al. 2010)

The most commonly known environmental, economic and social corporate data and information are being monitored, codified, registered and aggregated into Key Performance Indicators (KPIs) (Bassen, Kovacs 2009; DVFA 2009; IFAC 2012).

The sustainability performance is, however, often understood as performance in environmental, social and economic/ financial terms, thus excluding governance performance (Schaltegger, Wagner 2006). However, we shall also consider corporate governance (Bhojraj, Sengupta 2003).
Therefore, a conclusion can be drawn that ESG integration is currently becoming the investment strategy, whereby ESG indicators focus on the economic consequences of long-term risks and opportunities, associated with strategies of companies in which investments are being made. ESG performance indicators are becoming a tool for future cash flows. Primarily, investors want to achieve excellent financial returns under predetermined risk levels (Bartes 2010; Kocmanová, Němeček 2009).

Even with the growth of socially responsible investment (SRI) such ESG indicators are being incorporated into the investment assessment. Current financial crisis has shifted a stronger focus of the investors on the social and environmental conditions existing in the companies to be covered in their investment analyses. Many companies have also begun to ask themselves how to improve their communication skills on environmental, social and governance factors aiming at these mainstream investors (BSR 2011)

Corporate sustainability, that is the capacity of a company to continue operating over a long period of time, depends on the sustainability of its stakeholder relationships (Perrini, Tencati 2006).

\section{Environmental Performance}

An environmental performance indicator of a particular company (indicator of impact of company activity on its environment) is understood as a specific statement, facilitating the measurement of company's environmental performance. Development of environmental indicators has passed through a long evolution. Consumers more and more demand green products and services; on the other hand, businesses and industries are now much more responsive to green issues (Yildiz, Yercan 2011).

ČSN EN ISO 14000, mainly represented by generic standard ČSN EN ISO 14001, is applied in the ecologically oriented management system in the Czech Republic. The standards accompanying the establishment of systems of environmental management and their auditing shall be governed by the series of standards ČSN EN ISO 14000. The underlying philosophy of these international standards is to assist companies with all areas towards active and independent behaviour in environmental matters. 
Environmental performance indicators in the context of the Environmental Management Systems (EMS and EMAS) of the company should address primarily those company environmental impacts that are most significant and those which the company can influence by its operations, management, activities, products and services on environment and sustainable growth. They should fulfil dual purpose of assisting the management of the company and providing information to stakeholders (Hřebíček, Soukupová 2009).

Key Performance Indicators (KPIs) provide companies with a tool for measurement. KPIs help companies to implement strategies by linking various levels of such companies (organization units, departments as well as individuals) with clearly defined targets and benchmarks.

Corporate environmental (sustainable) reporting forms the part of company environmental communication that is directed from such a company to various target groups. Nowadays corporate environmental reporting has evolved to sustainability reporting, which covers a wider area of the company performance, also including economic and social aspects (Hřebíček, Soukupová, Kutová 2009; Schaltegger, Wagner 2012).

\section{Empirical research}

A number of successive steps have been taken to construct environmental indicators within the framework of the research. These relate to objective and subjective methods of selection of indicators/performance indicators and use of combination of various statistical methods.

Objective methods, e.g. on the basis of statistical analyses, represent the most appropriate method of the selection of indicators. They provide results based on clear algorithms, coming out only from actual values of such indicators Subjective indicators are based mainly on statements made by the respondents and their reflection of the investigated issue. Nevertheless, rational-logical point of view on monitored indicators is eliminated during the selection procedure. Thus, they are clearly subject to the person and investigated personality (Kuprová, Kamenický 2004). The instrument of efficiency's measurement is metrics i.e. strict financial or non-financial indicators or evaluative criteria which use efficiency's levels in specific area of enterprise. To analyse and control complex processes and phenomena, the knowledge of their inherent structure is needed (Ginevičius 2010).

The measurement of the contribution of an economic entity (company, etc.) to the sustainability poses a problem today and is subject to several debates. Based on the information provided by the organizational entities themselves and the information made public, the approach of sustainable value constitutes today the approach most accomplished to assess the sustainable performance (Rhouma 2010).

The impact of environmental matters on business performance is increasing and will continue to do so. For exam- ple, poor management of energy, natural resources or waste can affect current performance; failure to plan for a future in which environmental factors are likely to be significant may risk the long-term value and future of a business. Therefore, it is expected that company shall need to use environmental KPIs to adequately capture the link between more and more environmental, social and economic performance.

As it is clear from the analyses of international organizations (GRI, UNCTAD, IFAC, UN PRI, UNEP FI, OECD, IFRS, EFFAS-DVFA, CFA, etc.), which are dealing with the development of environmental, social and also corporate governance and economic indicators, there are coming to the front the ESG performance indicators, which they recommend to the investors to incorporate into their investment analyses and decision-making processes (CA 2012; CFA 2012; DVFA 2008; IFAC 2012; Nardo et al. 2005).

On the basis of such processed resources the questionnaire "PERFORMANCE OF THE COMPANY: ENVIRONMENTAL, SOCIAL, ECONOMIC ASPECTS AND GOVERNANCE" has been designed. Such proposed questionnaire has been compiled on the basis of achieved theoretical knowledge, defined areas of solved problem and specific objectives, so that the obtained results may contribute to the setup of key performance indicators (KPI) for the companies in the manufacturing industry according to CZ-NACE in the year 2012. Partial objective of the empirical research has been represented by the identification of key environmental performance indicators. Companies classified according to the legal forms of their businesses have been selected from the compiled database of companies and personally visited: 42 joint stock companies, 35 limited liability companies, 1 association and 1 state-owned enterprise classified in CZ-NACE in the processing industry, i.e. 79 companies with the number of employees over 250 according to the EU-criterion. From the ownership perspective, out of participating 79 companies 44 companies (55.7\%) are in the exclusively domestic ownership, 35 companies (44.3\%) are both subsidiaries of multinational corporations and companies with foreign investor.

Empirical research has focused primarily on the manufacturing companies: i.e. manufacture of electrical engineering, engineering, medical products- 31 companies (38.5\%), electricity, gas, water and waste processing - 12 companies (15.4\%), foundry production - 11 companies (14.1\%), manufacture of textiles and leather -9 companies (11.5\%), manufacture of chemicals - 8 companies (10.3\%), and manufacture of food products - 8 companies (10.3\%). Manufacturing companies have been deliberately selected for the reason of comparability of data; moreover, these are companies with strong field of action not only in the social and economic dimension, but also in the environmental field as regards the relationship to voluntary management instruments (see Table 1). 
Table 1. Voluntary management tools in the companies of the processing industry according to CZ-NACE

\begin{tabular}{c|c|c|c|c|c|c|c|c|c|c|c}
\hline Use & $\begin{array}{c}\text { ISO } \\
\mathbf{9 0 0 0}\end{array}$ & MRP & $\begin{array}{c}\text { ISO } \\
\mathbf{1 4 0 0 0}\end{array}$ & EMAS & $\begin{array}{c}\text { CHSN } \\
\text { OHSAS } \\
\mathbf{1 8 0 0 0}\end{array}$ & EMA & CSR & $\begin{array}{c}\text { Accounting } \\
\text { for } \\
\text { sustainable } \\
\text { development }\end{array}$ & $\begin{array}{c}\text { Cleaner } \\
\text { produc- } \\
\text { tion }\end{array}$ & $\begin{array}{c}\text { LCA } \\
\text { Environ-mental } \\
\text { labelling of } \\
\text { products }\end{array}$ \\
\hline No & 10.1 & 51.9 & 44.3 & 84.8 & 51.9 & 91.1 & 74.7 & 88.6 & 69.6 & 78.5 & 69.6 \\
\hline Yes & 89.9 & 48.1 & 55.7 & 15.2 & 48.1 & 8.9 & 25.3 & 11.4 & 30.4 & 21.5 & 30.4 \\
\hline
\end{tabular}

Method of selection of the investigated objects, i.e. companies, we can characterize as for a specific purpose and, moreover, based on a voluntary basis. But, as Reichel states, this is not considered insufficient in the qualitative research, because the ambition here "is not the representativeness, so ... the implementers consider such selection procedure reasonably as appropriate" (Reichel 2009).

From the voluntary management instruments in the companies of processing industry, the standard ISO 9000 is used with $89.9 \%$ of the companies, followed by the standard ISO 14000 with $55.7 \%$, although from the total number of companies it has been introduced only in half, the same also applies to the OHSAS $1800048.1 \%$ and MRP 48.1\%. The companies consider the other voluntary instruments for management less significant.

\section{Research methodology}

Methodology of determination of the environmental indicators took place in several stages.

The initial determination of the environmental indicators was based on the resources from the Global Reporting Initiative, EMAS III, and the International Federation of Accountants (GRI 3.12011 ; CZO 2012). Furthermore, the research dealt with environmental indicators which were published in the Statistical Environmental Yearbook of the Czech Republic (CZO 2012).

The selection of environmental indicators and related analyses was preceded by calculation of descriptors for each input variable.

To identify relevant indicators, selected sample of companies in the processing sector was asked: "Which environmental aspects, associated with the protection of environment, are significant and insignificant for the performance?" and "Which environmental aspects, associated with the use of natural resources and raw materials (including energy), significantly affect performance?". Respondents could express the fact of monitoring of the indicator in a range from "Yes" (4) to "No" (1). The questionnaires showed that for the companies the monitoring of the generation of waste was significant in $91.1 \%$, including hazardous waste in $70.9 \%$, emissions to air in $64.6 \%$, discharging of waste water in $59.5 \%$, smell, noise and vibration in 53.2\%. Insignificant were the influence on landscape in $58.2 \%$ and effects on soil in $60.8 \%$; however, some companies claimed monitoring of these aspects. Following the question, related to the use of resources and raw materials, the response indicated that the companies monitored the consumption of raw materials and consumables in $78.5 \%$, power consumption in $69.6 \%$. The response to the indicator relating to water consumption (36.7\%) and gas consumption (35.4\%) and consumption of heat $(24.1 \%)$ was most varied.

To the question "Which environmental indicators are monitored?" the respondents stated indicators used as environmental performance standards. The answers to this question confirmed the relevance of these indicators:

- energy efficiency: energy consumption (primary sources) $93.7 \%$,

- effectiveness of the material consumption: consumption of raw materials and consumables $91.1 \%$,

- waste management: total quantity of waste $82.1 \%$, hazardous waste $76.3 \%$,

- water management: water (total water consumption) $75.9 \%$, total quantity of discharged water $52.7 \%$.

A surprising result was the indicator of emissions to air, the respondents monitored emissions only in $37.5 \%$ for $\mathrm{NOx}, \mathrm{SOx}$ and other significant emissions, $39.7 \%$ made the total emissions of greenhouse gases; that did not match with the previous question on environmental aspects. The companies did not care about biodiversity indicator in $69.1 \%$. Other relevant indicators of the impact of the company activities on environment were the compliance with laws and regulations, the companies considered that as the most important indicator in $93.7 \%$, fines and penalties $78.2 \%$ and traffic $68.8 \%$.

The empirical research further tested the statistical significance (T-test) of the legal forms of companies or industry in relation to the environmental aspects of the performance; nevertheless, the testing did not provide any statistically significant results, in fact, there was no factual relationship between these factors (Field 2009; Meloun, Militky 2002). Identically, whether an owner of company was a foreign or domestic body did not indicate any influence on the relationship of the companies with their environment (see Table 2). 
Table 2. Relationship between the owner of company and the environmental aspect

\begin{tabular}{|c|c|c|c|c|c|c|c|c|c|}
\hline \multirow[t]{2}{*}{$\begin{array}{l}\text { Characte- } \\
\text { ristics }\end{array}$} & \multicolumn{2}{|c|}{$\begin{array}{l}\sum \text { of environmental } \\
\text { aspects related to } \\
\text { environmental } \\
\text { protection }\end{array}$} & \multicolumn{3}{|c|}{$\begin{array}{c}\sum \text { of environmental } \\
\text { aspects associated with the } \\
\text { use of natural resources }\end{array}$} & \multicolumn{2}{|c|}{$\begin{array}{c}\sum \text { of monitored } \\
\text { environmental indicators }\end{array}$} & \multicolumn{2}{|c|}{$\begin{array}{c}\Sigma \text { reducing the impact } \\
\text { on the environment }\end{array}$} \\
\hline & Domestic & Foreign & \multicolumn{2}{|c|}{ Domestic } & Foreign & Domestic & Foreign & Domestic & Foreign \\
\hline$N$ & 44 & 35 & \multicolumn{2}{|l|}{44} & 35 & 44 & 35 & 44 & 35 \\
\hline Mean & 4.1818 & 4.2286 & \multicolumn{2}{|l|}{3.4091} & 3.6 & 7.14 & 7.69 & 11.16 & 11.16 \\
\hline Std. dev. & 2.3355 & 2.0013 & 1.4030 & & 1.4184 & 2.237 & 2.04 & 3.18 & 2.62 \\
\hline \multirow{3}{*}{\multicolumn{3}{|c|}{ Variables }} & \multicolumn{7}{|c|}{ T-test for Equality of Means } \\
\hline & & & \multirow[t]{2}{*}{$t$} & \multirow{2}{*}{$d f$} & \multirow{2}{*}{$\begin{array}{l}\text { P-value } \\
\text { (2-tail.) }\end{array}$} & \multirow{2}{*}{$\begin{array}{l}\text { Mean diffe- } \\
\text { rence }\end{array}$} & \multirow{2}{*}{$\begin{array}{l}\text { Std. error } \\
\text { of diffe- } \\
\text { rence }\end{array}$} & \multicolumn{2}{|c|}{$\begin{array}{c}95 \% \text { confidence interval } \\
\text { of the difference }\end{array}$} \\
\hline & & & & & & & & Lower & Upper \\
\hline \multirow{2}{*}{\multicolumn{2}{|c|}{$\begin{array}{l}\sum \text { of environmental } \\
\text { aspects related to } \\
\text { environmental } \\
\text { protection }\end{array}$}} & EQVA* $^{*}$ & -0.094 & 77 & 0.925 & -0.046 & 0.496 & -1.036 & 0.942 \\
\hline & & $\mathrm{EQVNA}^{* *}$ & -0.096 & 76.5 & 0.924 & -0.046 & 0.488 & -1.019 & 0.925 \\
\hline \multirow{2}{*}{\multicolumn{2}{|c|}{$\begin{array}{l}\sum \text { of environmental } \\
\text { aspects associated } \\
\text { with the use of } \\
\text { natural resources }\end{array}$}} & EQVA* $^{*}$ & -0.598 & 77 & 0.552 & -0.190 & 0.319 & -0.826 & 0.444 \\
\hline & & $\mathrm{EQVNA}^{* *}$ & -0.597 & 72.6 & 0.552 & -0.190 & 0.319 & -0.828 & 0.446 \\
\hline \multirow{2}{*}{\multicolumn{2}{|c|}{$\begin{array}{l}\sum \text { of monitored } \\
\text { environmental } \\
\text { indicators }\end{array}$}} & EQVA* & -1.132 & 77 & 0.261 & -0.755 & 0.667 & -2.084 & 0.574 \\
\hline & & $\mathrm{EQVNA}^{* *}$ & -1.157 & 76.9 & 0.251 & -0.755 & 0.653 & -2.055 & 0.544 \\
\hline \multirow{2}{*}{\multicolumn{2}{|c|}{$\begin{array}{l}\sum \text { Reducing the } \\
\text { impact on the } \\
\text { environment }\end{array}$}} & EQVA* $^{*}$ & -1.127 & 77 & 0.263 & -0.549 & 0.487 & -1.520 & 0.421 \\
\hline & & $\mathrm{EQVNA}^{* *}$ & -1.139 & 75.5 & 0.258 & -0.549 & 0.482 & -1.510 & 0.411 \\
\hline
\end{tabular}

Testing the significance of the relationship between the owner of the company and position on the environment indicated an indirect transmission through voluntary management tools. Companies with foreign owners more often established standard ISO 14000 than companies with domestic owners (statistically significant, $t(75)=-2.1$, $P<0.05$, the strength of the effect, $r=0.24$ ). Still more often, companies with foreign owners introduced a management system for production planning and inventory (statistically significant, $t(77)=-2.9, P<0.05$, the strength of the effect, $r=0.31$ ). With other management instruments there were no differences between companies with domestic and foreign owners.

The perception of the significance of the environmental aspects (reduction of environmental impact, sum of the environmental indicators) in reference to the performance of the company was not affected by whether the company introduced ISO 14000 or not (see Table 3).

Application of ISO 14000, however, has a consequence for a particular conduct in the company concerning the relation to environment, i.e. that the company with ISO 14000 (compared with company without this standard) is trying more hard to reduce its impact on environment and, consequently, also to monitor more indicators relating to environmental performance. Using regression analysis, we are interested in how many more indicators the company will track if it has ISO 14000. For the formulation of dependencies we choose the simplest linear regression function $y=\beta_{1}+\beta_{2} x$ for Model 1 and Model 2.

Significance of the correlation coefficient $\mathrm{R}$ from Table 4 , the estimates of regression coefficients $(\beta)$ with P-values from Table 5, and the standard error (Std. error) from Table 4 indicate by how much -according to the regression modelthe monitoring of the environmental indicators would be increased in the company with implemented ISO 14000.

Significance of the correlation coefficient $R$ from Table 6, estimates of the regression coefficients ( $\beta$ ) with P-values from Table 7, and the standard error (Std. error) from Table 6 indicate by how much -according to the regression model- the monitoring of the environmental indicators would be increased in case of the ISO 14000 introduction to the company.

The results of regression analysis indicate that in case of the standard ISO 14000 introduction the company will seek to reduce the impact on environment in one more additional area and will also monitor, moreover, about two more environmental indicators.

Results of testing the significance (T-test) of the relationship between by ISO 14000 and whether the environmental aspects increased or improved performance are presented (see Table 8). 
Table 3. Relationship between ISO 14000 and the environmental aspects

\begin{tabular}{|c|c|c|c|c|c|c|c|c|}
\hline \multirow{3}{*}{\multicolumn{2}{|c|}{ Variables }} & \multicolumn{7}{|c|}{ T-test for equality of means } \\
\hline & & \multirow[t]{2}{*}{$t$} & \multirow[t]{2}{*}{$d f$} & \multirow{2}{*}{$\begin{array}{l}\text { P-value } \\
\text { (2-tail.) }\end{array}$} & \multirow{2}{*}{$\begin{array}{l}\text { Mean } \\
\text { diffe- } \\
\text { rence }\end{array}$} & \multirow{2}{*}{$\begin{array}{l}\text { Std. Error of } \\
\text { difference }\end{array}$} & \multicolumn{2}{|c|}{$\begin{array}{l}\text { 95\% confidence interval of } \\
\text { difference }\end{array}$} \\
\hline & & & & & & & Lower & Upper \\
\hline \multirow{2}{*}{$\begin{array}{l}\sum \text { of monitored } \\
\text { environmental } \\
\text { indicators }\end{array}$} & EQVA* $^{*}$ & 2.297 & 77 & 0.024 & 1.092 & 0.475 & 0.145 & 2.039 \\
\hline & $\mathrm{EQVNA}^{* *}$ & 2.218 & 60.5 & 0.030 & 1.092 & 0.492 & 0.108 & 2.077 \\
\hline \multirow{2}{*}{$\begin{array}{l}\sum \text { Reducing the } \\
\text { impact on the } \\
\text { environment }\end{array}$} & EQVA* & 2.825 & 77 & 0.006 & 1.810 & 0.641 & 0.534 & 3.085 \\
\hline & $\mathrm{EQVNA}^{* *}$ & 2.807 & 71.2 & 0.006 & 1.810 & 0.645 & 0.524 & 3.095 \\
\hline
\end{tabular}

\begin{tabular}{c|c|c|c|c}
\hline \multirow{2}{*}{ Characteristics } & \multicolumn{2}{|c|}{$\begin{array}{c}\text { of monitored environmental } \\
\text { indicators }\end{array}$} & $\begin{array}{c}\text { } \\
\text { reducing the impact } \\
\text { on environment }\end{array}$ \\
\cline { 2 - 5 } & $\begin{array}{c}\text { ISO 14000 } \\
\text { applied }\end{array}$ & $\begin{array}{c}\text { ISO 14000 } \\
\text { not applied }\end{array}$ & $\begin{array}{c}\text { ISO 14000 } \\
\text { applied }\end{array}$ & $\begin{array}{c}\text { ISO 14000 } \\
\text { not applied }\end{array}$ \\
\hline $\mathrm{N}$ & 44 & 35 & 44 & 35 \\
\hline Mean & 7.86 & 6.77 & 12.30 & 10.49 \\
\hline Std. dev. & 1.786 & 2.438 & 2.758 & 2.914 \\
\hline
\end{tabular}

Table 4. Testing of Model 1

\begin{tabular}{c|c|c|c|c}
\hline \multirow{2}{*}{ Model 1 } & $R$ & $R$ square & $\begin{array}{c}\text { Adjusted } R \\
\text { square }\end{array}$ & $\begin{array}{c}\text { Std. error of the } \\
\text { estimate }\end{array}$ \\
\cline { 2 - 5 } & 0.253 & 0.064 & 0.052 & 2.099 \\
\hline
\end{tabular}

Table 5. $\Sigma$ Reducing the impact on the environment by the introduction of ISO 14000

\begin{tabular}{c|c|c|c|c}
\hline \multirow{2}{*}{ Model 1 } & \multicolumn{2}{|c|}{ Coefficients } & \multirow{2}{*}{$t$} & \multirow{2}{*}{$P$-value } \\
\cline { 2 - 3 } & $\beta$ & Std. error & & \\
\hline Constant & 6.771 & 0.355 & 19.082 & 0.000 \\
\hline ISO 14 000 & 1.092 & 0.475 & 2.297 & 0.024 \\
\hline
\end{tabular}

Table 6. Testing of Model 2

\begin{tabular}{c|c|c|c|c}
\hline \multirow{2}{*}{ Model 2 } & $R$ & $R$ Square & $\begin{array}{c}\text { Adjusted } R \\
\text { square }\end{array}$ & $\begin{array}{c}\text { Std. error of } \\
\text { estimate }\end{array}$ \\
\cline { 2 - 5 } & 0.306 & 0.094 & 0.082 & 2.828 \\
\hline
\end{tabular}

Table 7. $\Sigma$ of monitored environmental indicators by the introduction of ISO 14000

\begin{tabular}{c|c|c|c|c}
\hline \multirow{2}{*}{ Model 2 } & \multicolumn{2}{|c|}{ Coefficients } & \multirow{2}{*}{$t$} & \multirow{2}{*}{$P$-value } \\
\cline { 2 - 3 } & $\beta$ & Std. Error & & \\
\hline Constant & 10.486 & 0.478 & 21.934 & 0.000 \\
\hline ISO 14000 & 1.810 & 0.641 & 2.825 & 0.006 \\
\hline
\end{tabular}

Table 8. Relationship between ISO 14000 and the environmental performance

\begin{tabular}{c|c|c|c|c|c|c}
\hline \multirow{2}{*}{ Characteristics } & \multicolumn{2}{|c|}{ They saved financial means } & \multicolumn{2}{c|}{$\begin{array}{c}\text { They have improved } \\
\text { competitiveness }\end{array}$} & \multicolumn{2}{c}{ They improved company image } \\
\cline { 2 - 7 } & $\begin{array}{c}\text { ISO 14000 } \\
\text { applied }\end{array}$ & $\begin{array}{c}\text { ISO 14000 } \\
\text { not applied }\end{array}$ & $\begin{array}{c}\text { ISO 14000 } \\
\text { applied }\end{array}$ & $\begin{array}{c}\text { ISO 14000 } \\
\text { not applied }\end{array}$ & $\begin{array}{c}\text { ISO 14000 } \\
\text { applied }\end{array}$ & $\begin{array}{c}\text { ISO 14000 } \\
\text { not applied }\end{array}$ \\
\hline$N$ & 42 & 35 & 40 & 34 & 41 & 35 \\
\hline Mean & 3.36 & 3.29 & 2.65 & 2.12 & 3.07 & 2.71 \\
\hline Std. dev. & 0.906 & 0.893 & 1.122 & 0.977 & 0.787 & 0.987 \\
\hline
\end{tabular}


Continued Table 8

\begin{tabular}{|c|c|c|c|c|c|c|c|c|}
\hline \multirow{3}{*}{ Variable } & & \multicolumn{7}{|c|}{ T-test for equality of means } \\
\hline & & \multirow[t]{2}{*}{$t$} & \multirow[t]{2}{*}{$d f$} & \multirow{2}{*}{$\begin{array}{l}\text { P-value } \\
\text { (2-tail.) }\end{array}$} & \multirow{2}{*}{$\begin{array}{c}\text { Mean } \\
\text { difference }\end{array}$} & \multirow{2}{*}{$\begin{array}{l}\text { Std. error of } \\
\text { difference }\end{array}$} & \multicolumn{2}{|c|}{$\begin{array}{c}\text { 95\% confidence interval o } \\
\text { difference }\end{array}$} \\
\hline & & & & & & & Lower & Upper \\
\hline \multirow{2}{*}{ Saved financial means } & EQVA $^{*}$ & 0.347 & 75 & 0.730 & 0.071 & 0.206 & -0.339 & 0.482 \\
\hline & $\mathrm{EQVNA}^{* *}$ & 0.347 & 72.9 & 0.730 & 0.071 & 0.206 & -0.339 & 0.482 \\
\hline \multirow{2}{*}{$\begin{array}{l}\text { Improved } \\
\text { competitiveness }\end{array}$} & EQVA* $^{*}$ & 2.157 & 72 & 0.034 & 0.532 & 0.247 & 0.040 & 1.024 \\
\hline & $\mathrm{EQVNA}^{* *}$ & 2.181 & 71.9 & 0.032 & 0.532 & 0.244 & 0.046 & 1.019 \\
\hline \multirow{2}{*}{$\begin{array}{l}\text { Improved company } \\
\text { image }\end{array}$} & EQVA* $^{*}$ & 1.763 & 74 & 0.082 & 0.359 & 0.204 & -0.047 & 0.765 \\
\hline & $\mathrm{EQVNA}^{* *}$ & 1.731 & 64.7 & 0.088 & 0.359 & 0.207 & -0.055 & 0.773 \\
\hline
\end{tabular}

Table 9. Key indicators of environmental performance

\begin{tabular}{|c|c|c|}
\hline Indicator & KPI & Measurement \\
\hline \multirow[t]{2}{*}{ EN1-Energy } & $\begin{array}{l}\text { Energy use } \\
\text { Total annual energy consumption } \\
\text { [MWh/CZK] } \\
\text { (indicator EN3 in GRI) }\end{array}$ & $\begin{array}{l}\text { Total direct (produced internally) and indirect (delivered) } \\
\text { energy consumption in megawatt divided by net sales. } \\
\text { (Total direct energy consumption = Electricity/heat } \\
\text { produced by the company) }\end{array}$ \\
\hline & $\begin{array}{l}\text { Renewable energy use } \\
\text { Total consumption of renewable energy } \\
\text { [\%](indicator EN3) }\end{array}$ & $\begin{array}{l}\text { Total of renewable energy sources in MWh x } 100 \text { divided by } \\
\text { total energy sources. }\end{array}$ \\
\hline \multirow[t]{2}{*}{ EN2-Materials } & $\begin{array}{l}\text { Material use } \\
\text { Annual mass flow of different used } \\
\text { materials (in addition to the carriers of } \\
\text { energy and water) } \\
\text { [t/CZK] (indicator EN1) }\end{array}$ & $\begin{array}{l}\text { Total consumption of materials in tons divided by total } \\
\text { operation costs. }\end{array}$ \\
\hline & $\begin{array}{l}\text { Recycled materials use } \\
\text { Proportion of the recycled input } \\
\text { materials [\%] (indicator EN2) }\end{array}$ & $\begin{array}{l}\text { Percentage content of used recycled materials out of total } \\
\text { consumption materials. }\end{array}$ \\
\hline \multirow{2}{*}{ EN3 - Waste } & $\begin{array}{l}\text { Production of waste } \\
\text { Total annual production of waste } \\
{[\mathrm{t} / \mathrm{CZK}] \text { (indicator EN22) }}\end{array}$ & Total waste use in tons divided by net sales. \\
\hline & $\begin{array}{l}\text { Production of hazardous waste } \\
\text { Total annual production of hazardous } \\
\text { waste }[\mathrm{t} / \mathrm{CZK}]\end{array}$ & Total hazardous waste use in tons divided by net sales \\
\hline EN4- Water & $\begin{array}{l}\text { Water Use } \\
\text { Total annual consumption of water } \\
{[\mathrm{m} 3 / \mathrm{CZK}](\text { indicator EN8) }}\end{array}$ & Total water use in cubic meters divided by net sales. \\
\hline EN5-Emissions & $\begin{array}{l}\text { Total annual emissions } \\
\text { [t/CZK](indicator EN20) }\end{array}$ & $\begin{array}{l}\text { Total emissions (solid particulate matter, } \mathrm{SO} 2, \mathrm{NOx}, \mathrm{NH} 3 \text {, } \\
\mathrm{PM} \text { without } \mathrm{CO} \text { ) in tonnes divided by net sales. }\end{array}$ \\
\hline EN6-Investment & $\begin{array}{l}\text { Environmental protection investment } \\
\text { [t/CZK] (indicator EN30) }\end{array}$ & $\begin{array}{l}\text { Total investments in environmental protection in CZK } \\
\text { divided by net sales. }\end{array}$ \\
\hline
\end{tabular}

Additional indicators

\begin{tabular}{l|l|l} 
& $\begin{array}{l}\text { Environmental laws and regulations } \\
\text { [number }] \text { (indicator EN28) }\end{array}$ & Number of voluntary agreements. \\
\cline { 2 - 3 } $\begin{array}{l}\text { with the rules on } \\
\text { the protection of } \\
\text { environment }\end{array}$ & $\begin{array}{l}\text { Fines and penalties } \\
{[\mathrm{CZK}] \text { (indicator EN28) }}\end{array}$ & $\begin{array}{l}\text { Monetary value of significant fines and total number } \\
\text { of non-monetary sanctions for non-compliance with } \\
\text { environmental legislation and regulations. The total } \\
\text { monetary value of significant fines; number of non- } \\
\text { monetary sanctions. }\end{array}$ \\
\hline
\end{tabular}


Continued Table 9

\begin{tabular}{l|l|l}
\hline \multicolumn{1}{c|}{ Indicator } & \multicolumn{1}{|c}{ KPI } & \multicolumn{1}{c}{ Measurement } \\
\hline $\begin{array}{l}\text { EN8- Significant } \\
\text { environmental } \\
\text { impacts }\end{array}$ & $\begin{array}{l}\text { Transport [t/km] } \\
\text { (Indicator EN29 in GRI) }\end{array}$ & $\begin{array}{l}\text { Greenhouse gas emissions } \\
\text { Total direct (produced internally) emissions of CO2 } \\
\text { equivalents in tonnes divided by number of covered } \\
\text { kilometres in company. }\end{array}$ \\
\hline EN9- Biodiversity & $\begin{array}{l}\text { Land use [\%] } \\
\text { of built-up surface } \\
\text { (partial indicator EN11) }\end{array}$ & $\begin{array}{l}\text { Total amount of land owned, leased, or managed for } \\
\text { production activities or extractive use in square meters } \mathrm{x} \\
100 \text { divided by the area of SCIs in hectare (according to } \\
\text { Natura 2000 Sites). }\end{array}$ \\
\hline
\end{tabular}

Companies with established ISO 14000 stated that environmental aspects established in their companies increased competitiveness, e.g. possibility to participate in selective proceedings of government contracts, in the remaining questions the influence of ISO 14000 was not identified (statistically insignificant).

\section{Results and discussion}

Key Performance Indicators (KPIs) are the essential assumptions of measuring environmental performance. The environmental performance indicators provide quantitative forms of a feedback reflecting the results in the framework of the corporate strategy. Environmental indicators, which particular company develops and informs about them in internal or external reports, always depend on the company strategic priorities, mirroring the unique character of every company. Key environmental indicators for the companies in the processing industry to measure performance are proposed (see Table 9).

Key performance indicators can help companies to plan and manage their environmental priorities, in particular, when the indicators are focused on the core business strategy, by means of operational plans, which include performance targets. The most important is to recognize what is measured, what is controlled, and important fact is that the measures create value for the company and its stakeholders.

Environmental indicators should be chosen by the company itself on the basis of their relevance and in terms of its strategy, these performance indicators should help companies to demonstrate progress towards the objectives of sustainability and ensure that they cover their environmental, social and economic impacts. Use of key performance indicators can be challenging in a particular organisational context. Prior to company decision as regards the establishment of scales of key performance indicators, it is necessary to understand how they can be best used and integrated into internal management and how they can help and support sustainable reporting. Managers must consider how to present the key performance indicators in their internal and external reporting. Identification and selection of key performance indicators depend on the context within the company and industry.

In the event that the company is of the opinion that some of selected environmental indicators are not relevant for evaluation of the performance, then it does not have to include such indicator in the overall evaluation of the performance.

\section{Conclusions}

Key performance indicators (KPIs) may help the companies to plan and control their priorities. The proposed environmental indicators should serve for the evaluation of ESG performance and they should meet some basic requirements: clarity, simplicity, real verification of data for their determination, taking into account the comprehensive problem and representativeness. The indicators should include the essential and characteristic features of ESG performance.

Environmental indicators have been selected from a wide range of performance indicators on the basis of the above available international sources. The proposal of environmental indicators and analysis were preceded by the calculation of descriptive characteristics of the individual variables. Descriptive statistics of all initial input indicators have been carried out, because certain specific variables have impact on the outcome of the methods in the follow-up phase and they can be revealed already in the descriptive statistics of the indicators.

These modifications have been preceded by one-dimensional analysis of all the variables with use of statistical methods and two-dimensional analysis; furthermore, the interrelations with T-test have been tested and correlation analysis has been employed.

The objective of the contribution is the construction of key environmental performance indicators. Empirical research deals with the selection of environmental performance indicators for CZ-NACE sector-manufacturing industry. ESG indicators quoted in an integrated reporting can provide relevant information, and even over time. 
The result of empirical research is the formulation of environmental indicators, which shall form the part of ESG performance indicators. Key Performance Indicators are formulated for companies involved in the manufacturing industry, according to CZ-NACE, with the use of statistical methods. Measurement of environmental indicators involves quantitative indicators requiring the information linked with company performance. Environmental performance indicators include: EN1-Energy, EN2-Materials, EN3-Waste, EN4-Water, EN5-Emissions, EN6-Investment. Additional indicators: EN-Compliance, EN8- Significant environmental impacts, EN9- Biodiversity.

The primary and crucial basis of the conception is the reporting of real-life conditions, their good knowledge, gathering of empirical data, when mainly the values of the mentioned ESG factors come to the fore, for the individual phases of the economic, environmental, social and corporate governance performances, while not only their values, but also their roles and priorities, content and functions and mutual interaction are monitored, and based on them formulation of proposals and methodical procedures as benefits to help boost company performance. Identification of measurable and relevant objectives for sustainability and appropriate metrics are a matter of the utmost importance.

\section{Acknowledgment}

This paper is supported by the project No. P403/11/2085 "Construction of Methods for Multifactor Assessment of Company Complex Performance in Selected Sectors" of the Czech Science Foundation and the research project "Management Support of Firms Using Quantitative Methods" of the Academy Sting, Business College in Brno in 2012.

\section{References}

Bassen, A.; Kovacs, A. M. 2009. Environmental, social and governance key performance indicators from a capital market perspective, Zeitschrift für Wirtschafts und Unternehmensethik 9(2): 182-192.

Bartes, F. 2010. Competitive intelligence-tool obtaining specific basics for strategic decision making TOP management firm, Acta Universitatis Agriculturae et Silviculturae Mendelianae Brunensis 58(6): 43-50.

BSR ESG in the Mainstream: The Role for Companies and Investors in Environmental, Social, and Governance Integration [online], [cited 17. June 2012]. Available from Internet: www.bsr.org

Bhojraj, S.; Sengupta, P. 2003. The effect of corporate governance mechanisms on bond ratings and yields: the role of institutional investors and outside directors, Journal of Business 76(3): 455-475. http://dx.doi.org/10.1086/344114

CA Environmental, Social and Governance (ESG) Issues in Institutional Investor Decision Making [online], [cited 17 June
2012]. Available from Internet: www.cica.ca/publications/ list-of publications/manual/item41881.pdf

CFA Institute Environmental, Social, and Governance Factors at Listed Companies: A Manual for Investors [online], [cited 18 June 2012]. Available from Internet: www.cfapubs.org/toc/ ccb/2008/2008/2

DVFA, KPIs for ESG. Key Performance Indicators for Environmental, Social and Governance Issues. A Guideline for Corporates on How to Report on ESG and a Benchmark for Investment Professionals on How to Integrate ESG into Financial Analysis. DVFA Financial Papers No. 8/08_e. DVFA, Dreieich.

Field, A. 2009. Discovering statistics using SPSS. London: SAGE. 324 p. ISBN-13 978-1847879073.

Garz, H.; Schnella, F.; Frank, R. KPIs for ESG. A Guideline for the Integration of ESG into Financial Analysis and Corporate Validation. Version 3.0, Frankfurt, DVFA/EFFAS [online], [cited 19 June 2012]. Available from Internet: http://www. dvfa.de/files/die_dvfa/kommissionen/non_financials/application/pdf/KPIs_ESG_FINAL.pdf

Ginevičius, R. 2010. Hierarchical structuring of processes and phenomena, Business: Theory and Practice 8(1): 14-18.

G3.1 Guidelines, 2011, G3.1 Guidelines [online], [cited 18 June 2012]. Available from Internet: http://www.globalreporting. org/ReportingFramework/G31/

Hřebíček, J.; Soukopová, J.; Kutová, E. 2009. Standardization of key performance indicators for environmental management and reporting in the Czech Republic, International Journal of Energy and Environment 4(4): 169-176.

Hřebíček, J.; Soukopová, J. 2009. Voluntary Company Assessment Report on the Linkages between Environment, Economy and Society (in Czech). Praha: Ministry of Environment of the Czech Republic. 61 p.

Hřebíček, J.; Piliar, F.; Soukopová, J.; Štencl, M.; Trenz, O. 2009. Corporate key performance indicators for environmental management and reporting, Acta Universitatis Agriculturae et Silviculturae Mendelianae Brunensis 59(2): 99-108.

IFAC. Investor Demand for Environmental, Social and Governance Disclosures [online], [cited 17 June 2012]. Available from Internet: http://www.ifac.org/publi-cations-resources/ investor-demand-environmental-social-and-governancedisclosures

Kocmanová, A.; Němeček, P. 2009. Economic, environmental and social issues and corporate governance in relation to measurement of company performance, in Liberec Economic Forum 2009. Liberec: University of Technology in Liberec, Faculty of Economic, 177-187.

Kocmanová, A.; Dočekalová, M. 2011. Corporate sustainability: environmental, social and corporate performance, Acta Universitatis Agriculturae et Silviculturae Mendelianae Brunensis (7): 203-209.

Kocmanová, A.; Dohnal, M.; Meluzin, T. 2011. Qualitative simple equationless models as simple integrators of vague sustainability knowledge items, Transformations in Business \& Economics 11(3): 187-196.

Kuprová, L.; Kamenický, J. 2004. Multi-factor analysis position limits Czech Republic in the years 2000-2004, Statistika 1(4): 303-315. 
Meloun, M.; Militký, J. 2002. Compendium Statistical Data Processing: Method and Problem Solution Including CD. Prague: Academia. 764 p. ISBN 80-200-1396-2.

Nardo, M.; Saisana, M.; Tarantola, S.; Saltelli, A. 2005. Handbook on Constructing Composite Indicators: Methodology and User Guide. OECD. http://dx.doi.org/10.1787/533411815016

Perrini, F.; Tencati, A. 2006. Sustainability and stakeholder management: the need for new corporate performance evaluation and reporting systems, Business Strategy and the Environment 1(15): 296-308. http://dx.doi.org/10.1002/bse.538

Reichel, J. 2009. Chapter Methodology of Social Research. Prague: Grada Publishing. 146 p. ISBN 978-80-247-3006-6.

Rhouma, A. B. 2010. Sustainable value in Europe: sustainability performance of the Czech Republic versus the Europe of Fifteen, E+M Ekonomie a Management 3(4): 16-29.

Ritschelova, I.; Sidorov, E., Farský, M. 2010. Impact of waste deposition fees on enterprises in the Czech Republic, $E+M$ Ekonomie a Management 3(2): 62-71.

Schaltegger, S.; Wagner, M. 2006. Managing Sustainability Performance Measurement and Reporting in an Integrated
Manner, Sustability Accounting as the Link between the Sustainability Balanced Scorecard and Sustainability Reporting. Dordrecht: Springer. 564 p. ISBN-13 978-1-874719-95-3.

Schaltegger, S.; Wagner, M. 2012. Integrative management of sustainability performance, measurement and reporting, International Journal of Accounting, Auditing and Performance Evaluation 3(1): 1-19.

Global Reporting Initiative. 2012. Sustainability Reporting Framework [online], [cited 18 June 2012]. Available from Internet: https://www.globalreporting.org/reporting/reporting-framework-overview/Pages/default.aspx

Statistical Environmental Yearbook of the Czech Republic 2011 [online], [cited 17 June 2012]. Available from Internet: http:// www.cenia.cz/web/www/web-pub2.nsf/\$pid/CENAXGA53MMQ2011

Yildiz, T.; Yercan, F. 2011. Environmental reporting on industrial and supply chain business processes within the context of sustainable development, Business: Theory and Practice 12(1): 5-14.

\begin{abstract}
Alena KOCMANOVÁ. Associate Professor at Department of Economics, the Faculty of Business and Management, Brno University of Technology. Research interests: corporate economics and environmental management. She takes part in resolving grant projects, research plans at the state and faculty level, Grant project of Czech Science Foundation and international projects. At the present time she is the co-researcher of the international projects in Latvia, Riga Technical University, Institute of Engineering Economics.
\end{abstract}

Zdeněk KARPÍŠEK. Associate Professor at Department of Economics, the Faculty of Business and Management and Faculty of Mechanical Engineering, Brno University of Technology. Research interests: fuzzy sets, stochastic modeling and applications in dealing with technical, scientific, medical and economic problems in the basic and applied research.

Markéta KLÍMKOVÁ. PhD Student, Faculty of Business and Management, Brno University of Technology, Research interests: lean production, environment management, different methods of operational and environmental management in manufacturing companies. 